Nur Rohman \& Jeka Widiatmanta, 2017. Pengaruh Dosis Pupuk Fosfor dan

Konsentrasi Giberelin pada Pertumbuhan dan Hasil Tanaman Kubis Bunga

(Brassica Oleraceea L.). Journal Viabel Pertanian. (2017), 11(2) 18-28

\title{
PENGARUH DOSIS PUPUK FOSFOR DAN KONSENTRASI GIBERELIN PADA PERTUMBUHAN DAN HASIL TANAMAN KUBIS BUNGA (Brassica oleraceea L.)
}

Nur Rohman ${ }^{1}$ ) dan Jeka Widiatmanta ${ }^{2)}$

1) Mahasiswa Prodi Agroteknologi, Fakultas Pertanian, Universitas Islam Balitar

2) Dosen Prodi Agroteknologi, Fakultas Pertanian, Universitas Islam Balitar

\begin{abstract}
The flower cabbage (Brassica oleraceea $L$.) is a type of vegetable plant belonging to the family of cabbage plants (Cruciferae). Flower cabbage often called "cauliflower" has many benefits to consume, because it contains calories, protein, carbohydrates, calcium, and vitamins $A, B 1$ and $C$. Farming is very much affected by the state of agricultural land, a problem that often occurs due to lack of elemental content nutrients in the soil that affect the inflorescence and flower cabbage growth. Therefore, to increase the yield of cabbage flowers offered the method of land optimization with the addition of nutrients in the form of phosphorous soil and also the addition of gibberellin hormone that has a role to flowering cabbage plants. The research was conducted by using Randomized Block Design (RBD) in divided plots with 2 treatments, Phosphorus $(P)$ as the main plot with 3 treatment levels P1 (100 kg / ha), $P 2(125 \mathrm{~kg} / \mathrm{ha})$ and P3 $150 \mathrm{~kg} / \mathrm{ha}$ then the concentration of Giberelin (K) as a subplot with 3 levels of treatment $\mathrm{K} 1(75 \mathrm{mg} / \mathrm{L}), \mathrm{K} 2(100 \mathrm{mg} / \mathrm{L})$ and $\mathrm{K3}(125 \mathrm{mg} / \mathrm{L}))$. From the result of the combination of the two treatments were 9 treatment combinations, repeated 3 times to obtain 27 units combination of treatments, each experimental plot consisted of 15 plants. Parameters observed include plant height, number of leaves, number of flowering plants, flower diameter and flower weight. The result of the research showed no significant interaction in all plant variables but the dosage of phosphorus fertilizer gave significant effect on the height variable of the 10 hst plant on the P1 (100 kg/ha) treatment, the leaf number variant showed significant effect at age 40 hst on $P 3$ treatment (150 $\mathrm{kg} / \mathrm{ha}$ ), the number of flowering plant variables showed significant effect of 60 hst on $P 3$ treatment $(150 \mathrm{~kg} / \mathrm{ha})$, flower diameter variables showed significant differences in $P 3$ treatment $(150 \mathrm{~kg} / \mathrm{ha})$. The best treatment is P3 treatment (150 $\mathrm{kg} / \mathrm{ha})$. Gibberellin concentrations did not have a real effect on all plant variants.
\end{abstract}

Keywords: Flower Cabbage, Phosphorus, and Giberelin 


\section{PENDAHULUAN}

Kubis bunga mempunyai peranan penting bagi kesehatan manusia, karena mengandung vitamin dan mineral yang sangat dibutuhkan tubuh, sehingga permintaan terhadap sayuran ini terus meningkat. Sebagai sayuran, kubis bunga dapat membantu pencernaan, menetralkan zat-zat asam dan memperlancar buang air besar. Menurut Rukmana (1994), komposisi zat gizi dan mineral setiap $100 \mathrm{~g}$ kubis bunga adalah kalori $(25,0 \mathrm{kal})$, protein $(2,4 \mathrm{~g})$, karbohidrat $(4,9 \mathrm{~g})$, kalsium $(22,0 \mathrm{mg})$, fosfor $(72,0 \mathrm{mg})$, zat besi1,1 mg ), vitamin A $(90,0 \mathrm{mg})$, vitamin B1 $(0,1 \mathrm{mg})$, vitamin C $(69,0 \mathrm{mg})$ dan air $(91,7 \mathrm{~g})$.

Dalam budidaya kubis bunga, pemupukan atau penambahan unsur hara tertentu untuk memenuhi kebutuhan tanaman yang tidak dapat disediakan oleh tanah sangat penting karena pemupukan dapat meningkatkan hasil panen dan kandungan nutrisi yang ada pada sayuran (Wang et al. 2008). Indeks panen secara signifikan meningkat seiring dengan meningkatnya aplikasi fosfor, penambahan fosfor secara terus menerus menyebabkan terjadinya akumulasi $\mathrm{P}$ pada permukaan atas tanah. Unsur hara fosfor $(\mathrm{P})$ merupakan salah satu unsur hara yang berperan penting dalam pembentukan bunga dan buah tanaman, sebab menjadi salah satu penyusun beberapa senyawa penting dan terlibat dalam berbagai reaksi biokimia tanaman.

Untuk membantu fungsi fosfor dalam fase pembungaan dapat ditambahkan dengan pengaplikasian zat pengatur tumbuh (Zpt) giberelin. Giberelin berfungsi merangsang pembungaan dan berperan dalam perkembangan bunga. Dosis penambahan fosor dan giberelin yang tepat dibutuhkan untuk mencapai hasil maksimal. Karena setiap tumbuhan dengan lingkungan hidup (tempat tanam) tertentu membutuhkan asupan unsur hara yang berbeda,hal ini dikarenakan pada proses metabolisme yang berbeda.

Berdasarkan penelitian Sutarwi (2013), pemupukan fosfor dengan dosis $150 \mathrm{~kg} / \mathrm{ha}$ menunjukan hasil panen yang terbaik pada kacang tanah dan menurut penelitian dari Wan arfiani barus dkk (2013), menyatakan bahwa penggunaan pupuk fosfor $200 \mathrm{~kg} / \mathrm{ha}$ meningkatkan jumlah bunga dan bobot polong pertanaman kacang hijau sebesar 224,83 gr dibanding dengan pemberian phospat $0 \mathrm{~kg} / \mathrm{ha}$, namun berbeda tidak nyata dengan pengguaan phospat $100 \mathrm{~kg} / \mathrm{ha}$ yakni sebesar $223,08 \mathrm{gr} / \mathrm{ha}$.

Berdasarkan hasil penelitian Sumani (2001), semakin tinggi aplikasi konsentrasi giberelin di ikuti dengan meningkatnya bunga, biji, dan jumlah umbi pada bawang merah dan pemberian 100 ppm (100 miligram/1 Liter air) hormon giberelin mampu memberikan keseimbangan hormonal yang sangat baik sehinga mampu merangsang inisiasi pembungaan sehinga mengasilkan persentase jumlah bunga terbanyak.

\section{METODOLOGI PENELITIAN}

\section{Waktu Dan Tempat}

Penelitian dilaksanakan pada 05 febuari sapai dengan 05 april 2017 di Dusun Rembang, Kelurahan Tepas Kec Kesamben Kab Blitar. 
Nur Rohman \& Jeka Widiatmanta, 2017. Pengaruh Dosis Pupuk Fosfor dan

Konsentrasi Giberelin pada Pertumbuhan dan Hasil Tanaman Kubis Bunga

(Brassica Oleraceea L.). Journal Viabel Pertanian. (2017), 11(2) 18-28

\begin{abstract}
Alat Dan Bahan

\section{Rancangan Percobaan} yang terdiri dari 3 taraf ialah :

Petak Utama : Dosis Pupuk (P) Fospor

P1 = Pemberian pupuk Fospor 100 kilogram/Hektar

$\mathrm{P} 2$ = pemberian pupuk Fospor 125 kilogram $/$ Hektar

P3 = Pemberian Pupuk Fospor 150 kilogram/Hektar
\end{abstract}

Alat yang di gunakan dalam penelitian ini diantaranya adalah meteran/penggaris dengan panjang $500 \mathrm{~cm}$ dan $30 \mathrm{~cm}$, timbangan dengan kapasitas $5 \mathrm{~kg}$, sprayer dengan kapasitas 14L, gayung, ember, cangkul, pipet, sabit, kater, dan alat tulis menulis.

Penelitian ini disusun secara faktorial dengan menggunakan Rancangan Acak Kelompok (RAK) dalam Petak Terbagi, Konsentrasi pupuk Fospor sebagai petak utama

Sedangkan Giberelin sebagai anak petak yang terdiri dari 3 taraf, ialah :

Anak Petak : Konsentrasi Hormon Giberelin (K)

$\mathrm{K} 1=$ pemberian 75 giberelin miligram/Liter

$\mathrm{K} 2=$ pemberian 100 giberelin miligram/Liter

$\mathrm{K} 3=$ pemberian 125 giberelin miligram/Liter

Dari hasil penggabungan kedua perlakuan tersebut diperoleh 9 kombinasi perlakuan, Perlakuan diulang 3 kali sehingga diperoleh 27 satuan kombinasi perlakuan, setiap plot percobaan terdiri dari 15 tanaman dan diambil 3 tanaman sebagai sempel sehinga tanaman total dalam percobaan 405 tanaman.

\title{
Variabel Pengamatan
}

Variabel yang diamati meliputi : tinggi tanaman, jumlah daun, jumlah tanaman yang berbunga, diameter bunga dan bobot bunga ragam (uji F) pada taraf $5 \%$. Bila hasil pengujian diperoleh perbedaaan yang nyata antar peerlakuan maka dilanjutkan dengan uji perbandingan antar perlakuan dengan menggunakan uji DMRT pada taraf 5\% dan dilanjut dengan uji regresi linier 5\%.

\section{Analisis Data} ragam (Anova).

Data pengamatan yang diperoleh dianalisis dengan menggunakan analisis sidik

\section{HASIL PENELITIAN DAN PEMBAHASAN}

\section{Tinggi Tanaman}

Hasil analisis sidik ragam (ANOVA) taraf 5\% dengan Rancangan Acak Kelompok (RAK) Dalam Petak Terbagi menunjukan bahwa tidak terdapat interaksi nyata antara pengaruh pemberian dosis pupuk fosfor $(\mathrm{P})$ dan konsentrasi giberelin $(\mathrm{K})$ peubah tinggi tanaman kubis bunga pada semua umur pengamatan. Pada perlakuan pemberian pupuk fosfor $(\mathrm{P})$ menunjukan pengaruh nyata pada peubah tinggi tanaman umur pengamatan 10 hst ,namun tidak terdapak pengaruh nyata pada pengamatan 20 30, 40, dan 50 hst. Sedangkan konsentrasi Giberelin (K) tidak menunjukan pengaruh nyata pada semua umur pengamatan. 
Nur Rohman \& Jeka Widiatmanta, 2017. Pengaruh Dosis Pupuk Fosfor dan Konsentrasi Giberelin pada Pertumbuhan dan Hasil Tanaman Kubis Bunga (Brassica Oleraceea L.). Journal Viabel Pertanian. (2017), 11(2) 18-28

Tabel 1.Pengaruh pupuk Fosfor $(\mathrm{P})$ dan konsentrasi Giberelin $(\mathrm{K})$ terhadap peubah tinggi tanaman kubis bunga pada berbagai umur pengamatan.

\begin{tabular}{cccccc}
\hline \multirow{2}{*}{ PERLAKUAN } & \multicolumn{5}{c}{ Tinggi Tanaman $(\mathrm{Cm})$} \\
& 10hst & 20hst & 30hst & 40hst & 50hst \\
\hline Fosfor & & & & & \\
P1 (100 kg/ha) & $7,80 \mathrm{~b}$ & $8,70 \mathrm{a}$ & $11,20 \mathrm{a}$ & $12,50 \mathrm{a}$ & $12,80 \mathrm{a}$ \\
P2 (125 kg/ha) & $7,17 \mathrm{a}$ & $8,19 \mathrm{a}$ & $10,71 \mathrm{a}$ & $12,74 \mathrm{a}$ & $12,94 \mathrm{a}$ \\
P3 (150 kg/ha) & $7,06 \mathrm{a}$ & $8,00 \mathrm{a}$ & $10,87 \mathrm{a}$ & $12,72 \mathrm{a}$ & $12,80 \mathrm{a}$ \\
Giberelin & & & & & \\
K1 (75 mg/L) & $7,30 \mathrm{a}$ & $8,19 \mathrm{a}$ & $10,72 \mathrm{a}$ & $12,56 \mathrm{a}$ & $12,42 \mathrm{a}$ \\
K2 (100 mg/L) & $7,60 \mathrm{a}$ & $8,58 \mathrm{a}$ & $11,44 \mathrm{a}$ & $12,46 \mathrm{a}$ & $12,92 \mathrm{a}$ \\
K3 $(125 \mathrm{mg} / \mathrm{L})$ & $7,12 \mathrm{a}$ & $8,12 \mathrm{a}$ & $10,62 \mathrm{a}$ & $13,80 \mathrm{a}$ & $12,80 \mathrm{a}$ \\
\hline
\end{tabular}

Keterangan : Angka-angka yang diikuti dengan huruf yang sama pada baris dan kolom yang sama tidak berbeda nyata dalam uji Duncan $(\alpha=0,05)$.

Hasil uji DMRT 5\% (Tabel 1) pada pemupukan Fosfor (P) menunjukan bahwa pengamatan umur $10 \mathrm{hst}$ menunjukan perbedaan nyata $\mathrm{P} 1(100 \mathrm{~kg} / \mathrm{ha})$ hasilnya tertinggi $7,80 \mathrm{~cm}$ dan P2 (125 kg/ha) hasilnya terendah $6,06 \mathrm{~cm}$, sedangkan umur 30, 40 dan $50 \mathrm{hst}$ menunjukan hasil yang tidak berbeda nyata. Hal ini diduga kandungan unsur hara yang dibutuhkan untuk pertumbuhan awal tanaman pada perlakuan P1 (100 kg/ha) tersedia dan langsung bisa dimanfaatkan untuk pertumbuhan, namun dengan dilakukannya pemupukan susulan dengan dosis yang sama sehinga unsur hara yang dibutuhkan pada perlakuan yang lain tersedia tinggi tanaman menjadi seragam atau sama. Hal ini sesuai dengan pendapat Gusti Eman A.S (2012), Tanah atau media tanaman adalah media tumbuh bagi tanaman yang dapat memasok sebagian unsur-unsur hara yang dibutuhkan oleh tanaman. Media tanaman (media tumbuh) merupakan salah satu unsur penting dalam menunjang pertumbuhan tanaman secara baik. Sebagian besar unsur-unsur hara yang dibutuhkan tanaman didapatkan melalui media tanaman yang selanjutnya diserap oleh perakaran dan digunakan untuk proses fisiologis tanaman.

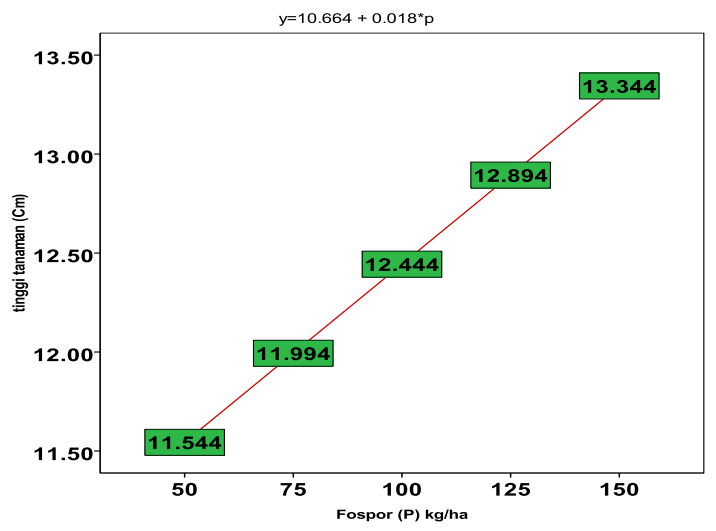

Gambar 1. Grafik uji regresi Pengaruh dosis pupuk posfor (P) terhadap peubah tinggi tanaman kubis bunga pada umur 10hst. 


\section{Jumlah Daun}

Hasil analisis sidik ragam (ANOVA) taraf 5\% dengan Rancangan Rancangan Acak Kelompok (RAK) Dalam Petak Terbagi menunjukan bahwa tidak terdapat interaksi nyata antara pengaruh pemberian dosis pupuk Fosfor $(\mathrm{P})$ dan konsentrasi Giberelin $(\mathrm{K})$ peubah jumlah daun tanaman kubis bunga pada semua umur pengamatan. Pada perlakuan pemberian pupuk fosfor $(\mathrm{P})$ menunjukan pengaruh nyata pada peubah jumlah daun umur pengamatan $40 \mathrm{hst}$, namun tidak terdapak pengaruh yang nyata pada pengamatan 10, 20, 30, dan 50 hst. Sedangkan konsentrasi Giberelin (K) tidak menunjukan pengaruh nyata pada semua umur pengamatan.

Tabel 2. Pengaruh dosis pupuk Posfor (P) dan konsentrasi Giberelin (K) terhadap peubah jumlah daun kubis bunga pada berbagai umur pengamatan.

\begin{tabular}{lccccc}
\hline & \multicolumn{5}{c}{ Jumlah Daun (helai) } \\
PERLAKUAN & 10hst & 20hst & 30hst & 40hst & 50hst \\
\hline Fosfor & & & & & \\
P1 (100 kg/ha) & $4.26 \mathrm{a}$ & $6.33 \mathrm{a}$ & $10.14 \mathrm{a}$ & $12.81 \mathrm{a}$ & $15.67 \mathrm{a}$ \\
P2 (125 kg/ha) & $4.49 \mathrm{a}$ & $6.60 \mathrm{a}$ & $10.40 \mathrm{a}$ & $14.89 \mathrm{~b}$ & $16.60 \mathrm{a}$ \\
P3(150 kg/ha) & $4.70 \mathrm{a}$ & $6.81 \mathrm{a}$ & $10.33 \mathrm{a}$ & $14.90 \mathrm{~b}$ & $15.67 \mathrm{a}$ \\
& & & & & \\
Giberelin & & & & & \\
K1(75 mg/L) & $4.44 \mathrm{a}$ & $6.67 \mathrm{a}$ & $10.38 \mathrm{a}$ & $14.17 \mathrm{a}$ & $15.49 \mathrm{a}$ \\
K2(100 mg/L) & $4.44 \mathrm{a}$ & $6.67 \mathrm{a}$ & $10.56 \mathrm{a}$ & $14.44 \mathrm{a}$ & $15.74 \mathrm{a}$ \\
K3(125 mg/L) & $4.56 \mathrm{a}$ & $6.40 \mathrm{a}$ & $9.67 \mathrm{a}$ & $14.03 \mathrm{a}$ & $16.11 \mathrm{a}$ \\
\hline
\end{tabular}

Keterangan : Angka-angka yang diikuti dengan huruf yang sama pada baris dan kolom yang sama tidak berbeda nyata dalam uji Duncan $(\alpha=0,05)$.

Berdasarkan hasil uji DMRT 5\% (Tabel 2) pada pemupukan fosfor (P) menunjukan bahwa pengamatan umur 40 hst menunjukan perbedaan nyata P2 (125 kg/ha) 14,48 helai dan P3 (150 kg/ha) 14,90 helai hasilnya tertinggi dan sedangkan P1 (100 $\mathrm{kg} / \mathrm{ha}$ ) 12,81 helai hasilnya terendah. Umur 10, 20, 30 dan 50 hst menunjukan hasil yang tidak berbeda nyata dari semua perlakuan. Hal ini diduga bukan disebabkan oleh pengaruh dari perlakuan, kandungan nutrisi yang masih tersedia pada tanah perlakuan P2 $(125 \mathrm{~kg} / \mathrm{ha})$ dan P3 (150 kg/ha) meyebabkan pertumbuan vegetatif masih berjalan. Hal ini sesuai dengan pendapat Mayun (2007) menyatakan bahwa jumlah daun dan luas permukaan daun dapat meningkatkan penangkapan cahaya dan $\mathrm{CO} 2$ yang lebih efektif, sehingga laju fotosintesis meningkat. Hasil fotosintesis ditranslokasikan ke daerah pemanfaatan vegetatif yaitu akar, batang dan daun yang mempengaruhi pertumbuhan dan perkembangan senhinga dapat menghambat pertumbuhhan generatif. 


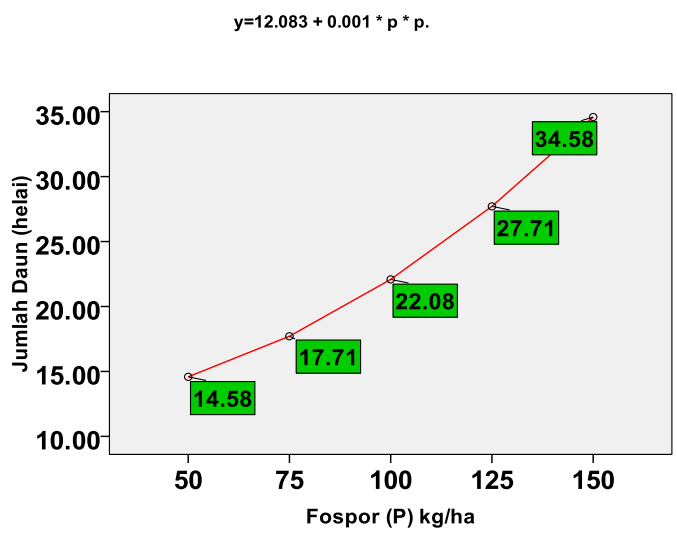

Gambar 2. Grafik uji regresi Pengaruh dosis pupuk posfor $(\mathrm{P})$ terhadap peubah jumlah daun tanaman kubis bunga pada umur 40hst.

\section{Jumlah Tanaman Yang Berbunga}

Hasil analisis sidik ragam (ANOVA) taraf 5\% dengan Rancangan Acak Kelompok (RAK) Dalam Petak Terbagi menunjukan bahwa tidak terdapat interaksi nyata antara pengaruh pemberian dosis pupuk fosfor $(\mathrm{P})$ dan konsentrasi giberelin $(\mathrm{K})$ peubah jumlah bunga tanaman kubis bunga pada semua umur pengamatan. Pada perlakuan pemberian pupuk fosfor $(\mathrm{P})$ menunjukan pengaruh nyata pada peubah jumlah bunga tanaman pada umur pengamatan $60 \mathrm{hst}$, namun tidak terdapak pengaruh nyata pada pengamatan 40 dan 50 hst. Sedangkan konsentrasi Giberelin (K) tidak menunjukan pengaruh nyata pada semua umur pengamatan.

Hasil uji DMRT 5\% pada (Tabel 3) pemupukan fosfor (P) menunjukan pengaruh yang nyata pada pengamatan 60 hst. Pada perlakuan P3 $(150 \mathrm{~kg} / \mathrm{ha})$ menunjukan nilai rata-rata tertinggi dari pada perlakuan lainnya $14,33 \mathrm{gr}$ dan P1 (100 kg/ha) menunjukan nilai rata-rata terendah daripada perlakuan lain 12,67 gr. Hal ini diduga pupuk fosfor dengan adalah termasuk unsur hara penting bagi tanaman dimana dosis pupuk tertentu sangat berpengaruh terhadap proses pembungaan dan pematangan tanaman kubis bunga. Hal ini sesuai dengan pendapat Hanum Cairani (2008). Fosfor adalah hara utama tanaman yang penting untuk perke mbangan akar, anakan, berbunga awal, dan pematanga. Fosfor memiliki sifat mobil dimana akan dapat diserap tanaman dalam waktu yang lama, oleh karena itu pupuk fosfor di aplikasikan saat 10-15 hari setelah penanaman dan akan dimanfaatkan pada pertumbuhan generatif tanaman sehinga dapat menigkatkan kualitas dan hasil. 
Nur Rohman \& Jeka Widiatmanta, 2017. Pengaruh Dosis Pupuk Fosfor dan Konsentrasi Giberelin pada Pertumbuhan dan Hasil Tanaman Kubis Bunga (Brassica Oleraceea L.). Journal Viabel Pertanian. (2017), 11(2) 18-28

Tabel 3. Pengaruh dosis pupuk Fosfor (P) dan konsentrasi Giberelin (K) terhadap peubah jumlah tanaman yang berbunga tanaman kubis bunga pada berbagai umur pengamatan.

\begin{tabular}{llll}
\hline \multirow{2}{*}{ Perlakuan } & \multicolumn{3}{c}{ Jumlah Tanaman Yang Bunga (Buah) } \\
& $40 \mathrm{Hst}$ & $50 \mathrm{Hst}$ & $60 \mathrm{Hst}$ \\
\hline Fospor & & & \\
P1 (fosfor 100kg/ha) & $0.67 \mathrm{a}$ & $6.56 \mathrm{a}$ & $12.67 \mathrm{a}$ \\
P2 (fosfor 125kg/ha) & $1.11 \mathrm{a}$ & $6.67 \mathrm{a}$ & $13.67 \mathrm{ab}$ \\
P3 (fosfor 150kg/ha) & $1.44 \mathrm{a}$ & $8.00 \mathrm{a}$ & $14.33 \mathrm{~b}$ \\
& & & \\
Gberelin & & & \\
K1 (giberelin 75mg/L) & $0.89 \mathrm{a}$ & $6.78 \mathrm{a}$ & $13.22 \mathrm{a}$ \\
K2 (giberelin 100mg/L) & $1.11 \mathrm{a}$ & $6.89 \mathrm{a}$ & $13.67 \mathrm{a}$ \\
K3 (giberelin 125mg/L) & $1.22 \mathrm{a}$ & $7.56 \mathrm{a}$ & $13.78 \mathrm{a}$ \\
\hline
\end{tabular}

Keterangan : Angka-angka yang diikuti dengan huruf yang sama pada baris dan kolom yang sama tidak berbeda nyata dalam uji Duncan $(\alpha=0,05)$.

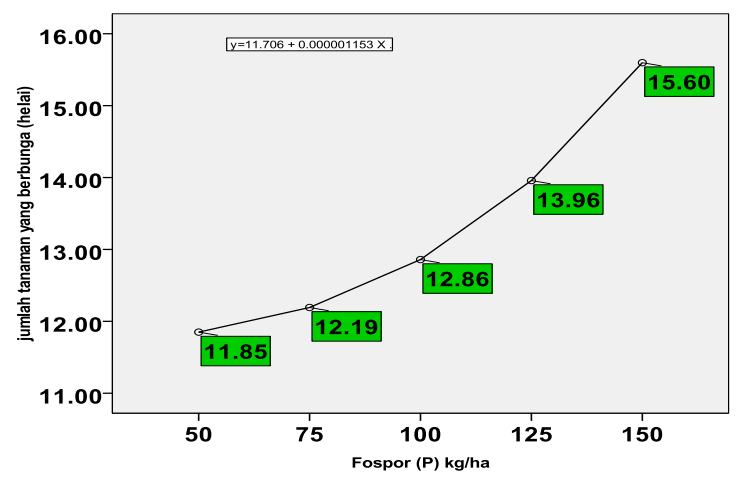

Gambar 3. Grafik uji regresi Pengaruh dosis pupuk posfor (P) terhadap peubah jumlah bunga umur $60 \mathrm{Hst}$.

\section{Diameter Bunga}

Hasil analisis sidik ragam (ANOVA) taraf 5\% Rancangan Acak Kelompok (RAK) Dalam Petak Terbagi menunjukan bahwa tidak terdapat interaksi nyata antara pengaruh pemberian dosis pupuk fospor $(\mathrm{P})$ dan konsentrasi giberelin $(\mathrm{K})$ peubah diameter bunga tanaman kubis bunga pada semua umur pengamatan. Pada perlakuan pemberian pupuk fosfor $(\mathrm{P})$ menunjukan pengaruh nyata pada perlakuan P3 (fosfor 150 $\mathrm{kg} / \mathrm{ha}$ ) peubah diameter bunga tanaman, namun tidak terdapak pengaruh nyata pada perlakuan P1 (fosfor $100 \mathrm{~kg} / \mathrm{ha}$ ) dan P2 (fosfor $125 \mathrm{~kg} / \mathrm{ha}$ ). Sedangkan konsentrasi Giberelin (K) tidak menunjukan pengaruh nyata pada semua perlakuan. 
Nur Rohman \& Jeka Widiatmanta, 2017. Pengaruh Dosis Pupuk Fosfor dan

Konsentrasi Giberelin pada Pertumbuhan dan Hasil Tanaman Kubis Bunga

(Brassica Oleraceea L.). Journal Viabel Pertanian. (2017), 11(2) 18-28

Tabel 4. Pengaruh dosis pupuk Posfor $(\mathrm{P})$ dan konsentrasi giberelin $(\mathrm{K})$ terhadap peubah diameter bunga kubis bunga.

\begin{tabular}{lc}
\hline \multicolumn{1}{c}{ PERLAKUAN } & $\begin{array}{c}\text { Diameter bunga }(\mathrm{Cm}) \\
60 \mathrm{Hst}\end{array}$ \\
\hline Fosfor & \\
P1 (fosfor 100kg/ha) & $6,42 \mathrm{a}$ \\
P2 (fosfor 125kg/ha) & $6,81 \mathrm{a}$ \\
P3 (fosfor 150kg/ha) & $7,69 \mathrm{~b}$ \\
Gberelin & \\
K1 (giberelin 75mg/L) & $7,14 \mathrm{a}$ \\
K2 (giberelin 100mg/L) & $6,86 \mathrm{a}$ \\
K3 (giberelin 125mg/L) & $6,92 \mathrm{a}$ \\
\hline
\end{tabular}

Keterangan : Angka-angka yang diikuti dengan huruf yang sama pada baris dan kolom yang sama tidak berbeda nyata dalam uji Duncan $(\alpha=0,05)$.

Hasil uji DMRT 5\% pada (Tabel 4) pemupukan fosfor (P) menunjukan pengaruh yang nyata pada perlakuan P3 (150 kg/ha) peubah diameter bunga. Pada perlakuan P3 $(150 \mathrm{~kg} / \mathrm{ha})$ menunjukan nilai rata-rata tertinggi dari pada perlakuan lainnya $7,96 \mathrm{~cm}$ dan P1 (100 kg/ha) menunjukan nilai rata-rata terendah daripada perlakuan lainnya $6,42 \mathrm{~cm}$. Hal ini diduga pengunaan pupuk fosfor pada awal tanam dapat berpengaru dalam fase generetif tanaman yaitu pembentukan bungga dan pematangan bunga, dimana pupuk fosfor mengandung unsur makro yang penting bagi tanaman dengan dosis yang tepat fospor dapat membantu dalam peyerapan unsur lain seperti $\mathrm{N}$ dan $\mathrm{K}$.

Hal ini sesuai dengan pendapat Hanum Cairani (2008). Fosfor adalah hara utama tanaman yang penting untuk perkembangan akar, anakan, berbunga awal, dan pematanga. Fosfor memiliki sifat mobil dimana akan dapat diserap tanaman dalam waktu yang lama, oleh karena itu pupuk fosfor di aplikasikan saat 10-15hari setelah penanaman dan akan dimanfaatkan pada pertumbuhan generatif tanaman sehinga dapat menigkatkan kualitas dan hasil.

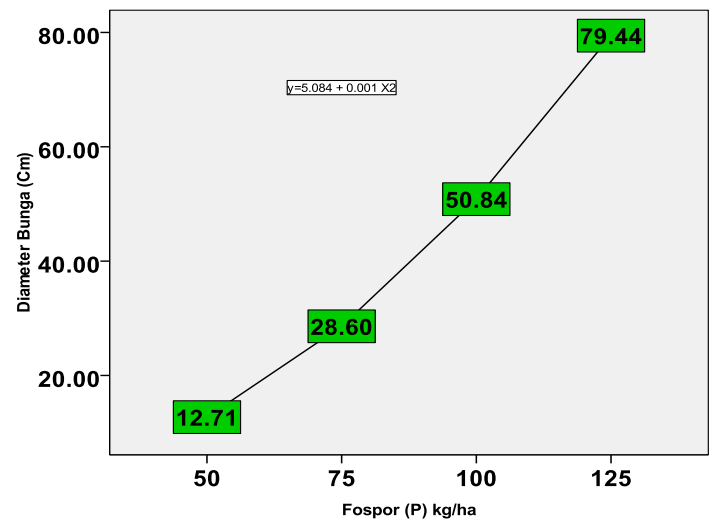

Gambar 5. Grafik uji regresi Pengaruh dosis pupuk posfor (P) terhadap peubah diammeter bunga tanaman kubis bunga pada umur 40hst. 
Nur Rohman \& Jeka Widiatmanta, 2017. Pengaruh Dosis Pupuk Fosfor dan

Konsentrasi Giberelin pada Pertumbuhan dan Hasil Tanaman Kubis Bunga

(Brassica Oleraceea L.). Journal Viabel Pertanian. (2017), 11(2) 18-28

\section{Bobot Bunga}

Hasil analisis sidik ragam (ANOVA) taraf 5\% dengan Rancangan Acak Kelompok (RAK) Dalam Petak Terbagi menunjukan bahwa tidak terdapat interaksi nyata antara pengaruh pemberian dosis pupuk fospor $(\mathrm{P})$ dan konsentrasi giberelin $(\mathrm{K})$ peubah bobot bunga tanaman kubis bunga. Pada perlakuan pemberian pupuk fosfor $(\mathrm{P})$ menunjukan pengaruh nyata pada peubah bobot bunga pada semua perlakuan. Sedangkan konsentrasi Giberelin (K) tidak menunjukan pengaruh nyata pada semua perlakuan.

Tabel 5.Pengaruh dosis pupuk Posfor $(\mathrm{P})$ dan konsentrasi giberelin $(\mathrm{K})$ terhadap peubah bobot bunga kubis bunga.

\begin{tabular}{lc}
\hline PERLAKUAN & $\begin{array}{c}\text { Bobot bunga } \\
55 \mathrm{Hst}\end{array}$ \\
\hline Fosfor & $45,40 \mathrm{a}$ \\
P1 (fosfor 100kg/ha) & $61,49 \mathrm{~b}$ \\
P2 (fosfor 125kg/ha) & $73,44 \mathrm{c}$ \\
P3 (fosfor 150kg/ha) & \\
Giberelin & $58,11 \mathrm{a}$ \\
K1 (giberelin 75mg/L) & $58,74 \mathrm{a}$ \\
K2 (giberelin 100mg/L) & $63,49 \mathrm{a}$ \\
K3 (giberelin 125mg/L) & \\
\hline gan : Angka-angka yang diikuti dengan huruf yang sama pada baris dan kolom \\
yang sama tidak berbeda nyata dalam uji Duncan $(\alpha=0,05)$.
\end{tabular}

Hasil uji DMRT 5\% pada (tabel 4) pemupukan fosfor (P) menunjukan pengaruh yang nyata pada semua perlakuan parameter bobot bunga. Pada perlakuan P3 (150 kg/ha) menunjukan nilai rata-rata tertinggi dari pada perlakuan lainnya 73,44 gr dan P1 (100 $\mathrm{kg} / \mathrm{ha}$ ) menunjukan nilai rata-rata terendah dari pada perlakuan lainnya 45,40 gr. Hal ini diduga pupuk fosfor sangat berpengaruh pada pertumbuhan generatif atau pembungaan tanaman dimana pemberian pupuk fosfor dengan dosis yang tepat dan diberikan pada awal tanam akan semakin perpengaruh pada pembungaan. Hal ini sesuai dengan pendapat Sarief (1986), Pemupukan yang sesuai dengan dosis yang dibutuhkan tanaman mendukung meningkatnya efisiensi serapan bahwa pertumbuhan tanaman dan produksi tanaman akan mencapai optimum apabila faktor penunjang pertumbuhan dalam keadaan optimal, unsur-unsur yang dimaksud adalah nutrisi yang dibutuhkan tanaman terutama $\mathrm{N}$, $\mathrm{P}$ dan $\mathrm{K}$ berada dalam keadaan optimum dan tersedia bagi tanaman serta unsur hara mikro tambahan lainnya. 


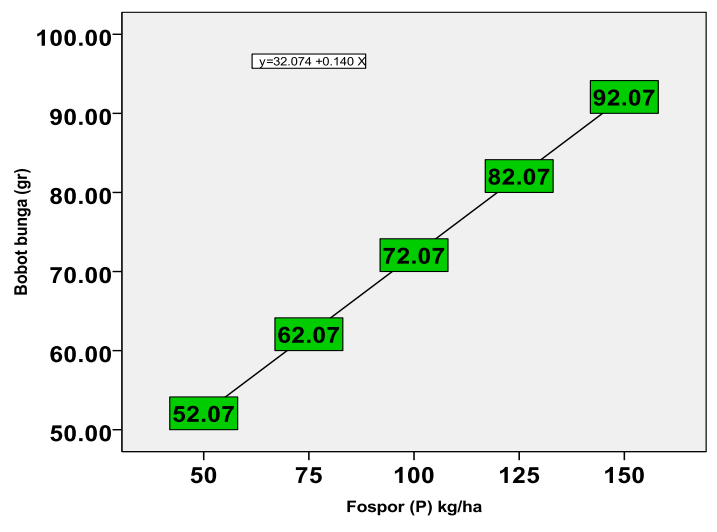

Grafik 6.Grafik uji regresi Pengaruh dosis pupuk posfor (P) terhadap peubah bobot bunga tanaman kubis bunga pada umur 60 hst.

\section{Kesimpulan}

Berdasarkan hasil penelitian mengenai Pengaruh Macam Dosis Pupuk Fosfor (P) Dan Konsentrasi Giberelin (K) Terhadap Pertumbuhan Dan Hasil Tanaman Kubis Bunga dapat disimpulkan sebagai berikut :

1. Dari hasil penelitian tidak terdapat interaksi nyata pemberian dosis pupuk fosfor dan konsentrasi giberelin pada semua peubah pengamatan.

2. Dosis pupuk fosfor memberikan pengaruh nyata pada peubah tinggi tanaman umur 10 hst pada perlakuan P1 (100 kg/ha), peubah jumlah daun terdapat pengaruh nyata pada umur 40 hst pada perlakuan P3 $(150 \mathrm{~kg} / \mathrm{ha})$, peubah jumlah tanaman yang berbunga terdapat pengaruh nyata umur 60 hst pada perlakuan P3 $(150 \mathrm{~kg} / \mathrm{ha})$, peubah diameter bunga terdapat perbedaan nyata pada perlakuan P3 $(150 \mathrm{~kg} / \mathrm{ha})$ dan pada peubah berat bunga terdapat pengaruh nyata pada perlakuan P3 (150 kg/ha). Perlakuan terbaik adalah perlakuan P3 (150 kg/ha).

3. Konsentrasi giberelin tidak memberikan pengaruh nyata pada semua peubah tanaman.

\section{Daftar Pustaka}

Barus, Wan Arfani dkk. 2013. respon pertumbuhhan dan produksi kacang hijau akibat pemberian pupuk organik cair dan pupuk tsp. Agrium Vol. 19 (1) : 1-11

Cahyono, B. 2001. Kubis Bunga dan Broccoli. Kanisius. Yogyakarta

Fei L, el all 2011. Effects of phosphorus accumulation in soil with the utilization ages of the vegetable greenhouses in the suburb of Shenyang. Procedia Environmental Sciences 8:16-20. DOI: 10.1016/j.proenv.2011.10.005.

Hanum, Chairani. Teknik Budidaya Tanaman Jilid 3 untuk SMK. Jakarta. Direktorat Pembinaan Sekolah Menengah Kejuruan, Direktorat Jenderal Manajemen Pendidikan Dasar dan Menengah, Departemen Pendidikan Nasional, 2008. 
Mayun, I.A, 2007. Efek Mulasa Jerami Padi dan Pupuk Kandang Sapi Terhadap Pertumbuhan dan Hasil Bawang Merah Didaerah Pesisir. Agritrop, 26 (1) : 3340.

Rudi dan Tri Harjon. 2012. Karakter hasil biji kacang hijau pada kondisi pemupukan $\mathrm{P}$ dan insensitas peyiangan yang berbeda. Jurnalagrivor 11 (2) :137-143

Rukmana, R. 1994. Budidaya Kubis Bunga dan Broccoli. Kanisius, Yogyakarta. 64 hlm.di dalam Ainun Marliah et al. (2013)

Wang Y, Zhang Y. 2008. Soil-phosphorus distribution and availability as affected by subsurface irrigation. J Plant Nnutr Soil Sci. 173:345-352. DOI : 10.1002/jpln.200800284. 